\title{
PECULIARITIES OF THE TRANSLATION OF ENGLISH ECONOMIC TERMS INTO RUSSIAN
}

\begin{abstract}
Summary. The article deals with the translation of economic terms being in a great demand due to the development of such aspects of economic activity as a bank system, finance, audit, accounting, marketing, international trade. The aim in translating economic terms is to convey the most correct translation taking into account the differences existing in economic realities of the countries. The article dwells upon lexical and grammatical features and the equivalence of terms. It is emphasized that due to the typological differences between Russian and English certain semantic differences should be observed when translating terms. The article deals with the analysis of the essential characteristics, which define general and special peculiarities of the notion "term". Different approaches of scientists regarding the translation methods of the terms are revealed in the article. The article describes various types of terms in terms of morphology and according to the number of their constituent components. It presents the analysis of the most common terminology models. The examples given in the article prove that economic terms cannot be characterized as "lexical units" indifferent to the context. The presence of synonymous connections and ambiguity confirm the relevance of the study. The article provides a description of terminilogical vocabulary requirements: accuracy, unambiguity, brevity, consistency, stylistic neutrality, indifference to the context, the absence of synonyms and homonyms, etc. Since in Russian and English multicomponent terms numerically prevail over singleelement ones, special attention is given to different methods of multicomponent terms translation: tracing, the use of the genitive case, functional replacement, compression, addition, modulation, a combination of several translation methods. It is stressed that in the process of translating multicomponent terms it is necessary to perform semanticsyntactic analysis, as a thoughtful analysis of the term is the key to a successful translation.
\end{abstract}

Key words: term, economic term, translation method, one element term, multicomponent term, terminology, terminology model.

The topicality of the article. One of the characteristics of the present time is globalization, which is accompanied by the interpenetration of the economies of different states. Economic interaction requires overcoming all kinds of barriers - not only political, legal, customs, but also communicative. Therefore, in the field of economics there is a need to develop an internationally accepted terminological fund and to create lexicographic sources containing a qualitative translation of economic terms. In addition, the economic sector is constantly evolving and its forms and content are transforming. These processes also cause changes in the lexical composition serving the speech interaction of economic sector communicators.

New economic models have emerged, which has led to the creation of a new system of terms and the appearance of difficulties in translating economic texts, which have rushed to us from abroad and are of particular interest to study. The translation of economic terms in a modern world has been in a great demand due to the development of a bank system, marketing strategy, management of organizations and international trade. A teacher, a student or a translator can translate the economic text, but its sense will be false because of poor knowledge of economics. While translating economic terms from English into Russian one faces different types of documentation (customs, banking, stock exchange, audit, finance, etc.), and only an economist can understand this information. Thus, a teacher, a student or a translator should possess not only linguistic knowledge, but also knowledge of economics.

Innovation technologies, finance and banking, stock exchanges and investments, marketing, management systems, audit, insurance and much more are all different aspects of economic activity. Each system in terms of linguistics has its own structure of terms, which is sometimes common to several systems at the same time. Thus, terminology comes to the fore as a special layer of a language that makes business communication possible. The aim in translating economic terms is to convey the most correct translation taking into account the differences existing in the economic realities of the countries. It can only be achieved if equivalent terms are found.

The task in our case is not always simple, since many terms appeared in the Russian language have relatively recently been borrowed from the same English language, and the concepts to which they correspond are either completely absent or just formed under the influence of our economic realities. In this regard, it is practically impossible to give an absolutely accurate translation of one or another term, since the conditions for economic activity are different in different countries. That is, without a deep knowledge of the subject "economics" and the peculiarities of its application in the particular country, the translation of terms will be inadequate to some extent.

The previous studies. In spite of the stable and continuous progress in translation of special terms and texts in different spheres of scientific-technical activity, the research on the form and content of special terms and ways of their translation has never been stopped. The problem of term-systems and terminology models formation and methods of translating English terms have been of great interest for a great deal of linguists for a long time.

The theoretical basis of the research were the works of famous authors on the problems of term-system functioning: M.M. Glushko, A.A. Reformatskyi, D.E. Rosental, M.A. Telenkova, D.S. Lotte, P.A. Florenskyi and others. A great number of scientists devoted their works to different aspects of translation science: L.S. Barkhudarov, R.F. Pronina, Y.I. Retsker, Zh.-P. Vine and Zh. Dardelne, V.N. Komissarov, V.A. Tatarinov. 
Multicomponent terms, existing in texts of different specialities, have become the object of special interest many times. The termsystem of economic theme in the translation aspect was presented in the works of S.A. Frolova, T.S. Schuliukina, Zh.V. Lesnikov, V.I. Karaban and other scientists. They have different conceptions on the ways of term translation. These disagreements make it necessary to examine and amplify different translation techniques.

The aim of the article is to analyze the specific features of structure, semantics and translation of English economic termwords and term-phrases into Russian (on the basis of English texts on economics) and explain the importance of adequate terminology translation.

Discussion. The relevance of this topic is due to the need for studying terminology and how to translate it in economic texts. It should be taken into account that when translating economic texts or terms it is important to consider their lexical and grammatical features. Speaking about the equivalence of terms, it should be noted that due to typological differences between Russian and English, certain semantic differences are observed when translating terms. Many terms may be terms in different areas. It is also possible to use several special lexical items. In this regard, we can talk about the ambiguity, homonymy and synonymy of terms. In terms of morphology, terms are divided into simple (share, account, supply, demand, lease, tax), derivatives (productivity, performance, liquidity, movables, profitability, mobility), complex (stockshare, stockholder, warehouse, turnover, wageworker, wallflower, stakeholder), phrases (bank account, opportunity costs, marginal utility, equity capital, capital goods, sales promotion, stock exchange), abbraviations (LLC - limited liability company, ASA American Standards Association, BT - Board of Trade, VAT - value added tax, GDP - gross domestic product, GNP - gross national product, IMF -the International Monetary Fund). Depending on the number of their constituent components, the term-combinations can be two-term, three-term and polynomial [3, p. 32-34].

Terminology is an extensive class of special vocabulary with a large content of international words. Many terms are borrowed from language to language or through another language, as well as many are of Greek-Latin origin. With the help of the term you can clearly and briefly convey the essence and content of the designated object. It is characterized by correlation with a precisely defined concept and striving for unambiguity within the same terminology, therefore many English terms have constant lexical correspondences in the Russian language: depositor - вкладчик, income - доход, auction - аукцион, share - доля, часть, slump - падение, упадок, fluctuation - колебание, неустойчивость.

As recommendations, when translating terms it is necessary to rely on context. An explanatory dictionary or reference source can help clarify the meaning of a term. For example, the word "rate" means «ставка» in the phrase "interest rate", but in the phrase "inflation rate" it means «уровень». The word "value" means «стоимость», but in the phrase "advertising value" it means «действенность» $[11$, p. 155]. It is also necessary to take into account geographical and regional geographic realities, to be able to "pick up the lexical correspondence of a term or use tracing when there is no equivalent in the source language", "check the use of one or another English term in the original before" [1, p. 115-116]. Thus, when translating terms, it is necessary to take into account the scope of their application and context, as well as semantic connections between components in terms of phrases.
As practice shows, the greatest difficulty in translating economic terms are terms that consist of two words or more and denote a single concept or phenomenon of economic activity. In Russian and English, multicomponent terms numerically prevail over singleelement terms. In this regard, it seems reasonable to pay special attention to multi-element terms. V.A. Sudovtsev understands "terminological phrases, which are semantic integral combinations of two or more words, connected with the help of a preposition or in a direct way" $[10$, p. 53].

Translation of terms and phrases always causes certain difficulties. The technology for translating multicomponent terms involves first of all an appeal to the determining component (main word), which is a generic concept in relation to the whole term and often expresses the main meaning of the term. This is indicated by experts in the field of translation activity: "The translation of terms and phrases begins with the translation of the noun, which is the main component, and then each semantic group is translated sequentially, most often from right to left" $[8$, p. 21]. Depending on whether the translation language has direct correspondences to the units of the original language, Y.I. Retsker introduces concepts such as analogue and equivalent. According to his works, three main types of term translation can be distinguished: 1) translation using equivalent; 2) search for an analogue; 3 ) descriptive translation [8, p. 74].

But not each term has one single translation option (equivalent). Equivalent is not only a word, but also a phrase. And since descriptive translation is most often used in the translation of terms, the creation of bulky terms should be avoided, unless the use of a shorter version of the translation does not impair the transmission of meaning and meets the communicative task. When translating the term, one must remember that the main component should denote the category to which the object belongs, express the generic concept, and the determining component should reflect characterizing features that distinguish it from other objects or phenomena of the same kind.

When translating multicomponent terms, it is necessary to establish a keyword and internal semantic connections [6, p. 49]. For example, if you translate the term "quality control report", first we translate the keyword "report" - «отчет», then "control" «контроль» and then the word "quality" - «качество». As a result, we obtain - «отчет о контроле качества». Some more examples: "manufacturing cost sheet" - смета издержек производства, "single-firm monopoly" - монополия одной фирмы, "assets valuation reserve" - резерв оценки имущества, "overseas market research" - изучение зарубежных рынков сбыта.

Due to the difference between the language systems of the Russian and English languages, when translating the text you have to swap the defined and defining word, i.e. the defining word in the source language should express the generic concept in the translating language. R.F. Pronina [7, p. 20-21] offers five basic techniques for translating multicomponent terms:

1) translation using Russian words and phrases, literally reproducing words and expressions of the English language (the so-called tracing);

2) translation using the genitive case;

3) translation using various prepositions;

4) translation of one of the parts of the phrase by a group of explanatory words (descriptive translation);

5) translation with a change order of the attribute group components (permutation). The final choice of one or another way 
of translating multicomponent terms depends on the lexical content of the attributive components of a given term and on the semantic understanding of the context.

Therefore, in the process of translating multicomponent terms, it is necessary to perform semantic-syntactic analysis [7, p. 102]. To do this: 1) translate a keyword, as a rule, the last word in a terminological group; 2) analyze the semantic relationships between the components of the term and highlight the semantic groups; 3) establish links between the distinguished semantic groups and translate the entire terminological group; 4) perform a stylistic analysis and edit the translation.

Thus, we can say: a thoughtful analysis of the term is the key to a successful translation. Terminological vocabulary has the following requirements: unambiguity, accuracy, brevity, consistency, stylistic neutrality, indifference to the context, the absence of synonyms and homonyms within the same terminological system, etc. And, as a rule, "ideal" terms meet these requirements. The frequency of use of the same terms indicates that they for the most part do not have synonymous connections.

Multicomponent terms in the original texts often demonstrate synonymy, but they cannot be characterized as "lexical units" indifferent to the context.

The presence of synonymous connections and ambiguity confirm the relevance of the study: in order to select adequate matches for the terms of the economic sphere, the teacher or translator must take into account the context of the translated lexical unit, which means that he/she is faced with the task of choosing the most productive, relevant translation strategy. It seems that translation strategies may be determined by specific substantive and formal characteristics of the terms analyzed in the article. In terminological studies, classifications are common, the basis of which is the partial affiliation of the components that form the analyzed terms.

The study identified the following terminology models:

1. Noun + Noun:

Unemployment benefit - пособие по безработице; market demand - рыночный спрос; consumer goods - потребительские товары; sales revenue - доходы от продаж; loan capital - ссудный капитал; product release - выпуск продукции; quality survey контроль качества.

\section{Adjective or Participle + Noun:}

Marginal revenue - предельный доход; aggregate demand совокупный спрос; indirect tax - косвенный налог; competitive advantage - преимущество, основанное на конкуренции; final goods - готовая продукция; owned capital -собственный капитал.

\section{Noun + preposition + Noun:}

Means of production - средства производства; unit of output - единица продукции; return on capital - прибыль на акционерный капитал; unit of account - расчетная единица; volume of expenditures - объем расходов; amount of business торговый оборот; tax on a patent - патентная пошлина.

4. Multicomponent terms: fixed assets unit - единица реального основного капитала; tangible capital stock-фонды материальных активов; foreign-trade deal -внешнеторговая сделка; retained contribution account - счет отчислений от прибыли; foreign market survey - обзор зарубежных рынков.

In the process of translation, due to their specific characteristics, economic multicomponent terms cause a number of difficulties. On the one hand, the translation of economic terms requires clarity and accuracy. On the other hand, the translator needs to choose an equivalent term that matches the economic theme. Therefore, to translate multicomponent terms in economic texts, the translator often has to use not one, but several methods of translation at once. In the process it was revealed that tracing is the most common way of transferring English multicomponent terms into Russian. Perhaps one of the reasons for the frequent use of this method of translation is the presence of a large number of borrowings from Latin and Greek in English. When tracing occurs a word-by-word translation of each element of the term is used. The use of this translation method is possible in the absence of obvious contradictions between the grammatical and lexical systems of the Russian and English languages.

In economic texts terms translated through the use of the genitive case are relatively rare. The translation of these terms into Russian is constructed according to the same scheme: both nouns are translated, the second of which is in the genitive case with respect to the first. Basically, the translation of such terms can be carried out without regard to the context. Functional replacement as a way of translating economic terms in terms of frequency of use is on the second place after tracing. This technique is used in cases where none of the values recorded in the dictionary matches the context. Compression, that is, the compression of an expression or phrase, is a characteristic phenomenon in the English language. When comparing the two languages, this phenomenon is very obvious. Addition or deployment is the opposite of compression. Since the structures of English and Russian sentences and phrases are different, as usual, compressed English sentences require a more detailed expression of thought in Russian. Transposition is a way of translating lexical units, which consists either in transferring any language form (for example, using the present tense instead of the future), or in replacing one part of speech with another without changing the meaning of the whole message. The modulation method is used, if necessary, in the process of translating an equivalent which value would logically follow from the value of the original unit. Moreover, often the meanings of a foreign word and its equivalent have a causal relationship. One of the common translation methods is a combined method. This method is used by teachers or translators in cases where the use of only one translation transformation is not enough for an adequate translation of the term. In the process of comparing English terms with Russian equivalents, the following tendency was revealed: in English there are more elements in the term, in Russian there are fewer elements, but more syllables, so the Russian term tends to be shortened so as not to look bulky. There is a high frequency of replacement of English three-element terms, and in some cases five-element terms by two-element ones when translating into Russian. Such a replacement is typical when using almost all translation methods: two-way trade - двусторонняя торговля, renewable natural reserves - возобновляемые природные ресурсы (tracing); buy-back arrangement - компенсационное соглашение, smallscale trades - мелкие предприятия, job shop-type production мелкосерийное производство (compression); sale of services продажа услуг, value of money - ценность денег (using genitive case); cost related prices - переменные цены, take-home pay чистая получка (functional replacement).

But there is also a reverse phenomenon, when in English we use a two-element term, and in Russian - a three-element 
equivalent. This happens when we use such translation methods as addition and modulation: forward trading - заключение сделок на срок, development reserve - резерв на расширение предприятия.

Conclusion. The problems of the translation of economic terms are devoted to research and study not only in our country, but above all, abroad. As mentioned above, globalization is a universal process, and it is the English language that plays the role of the main tool for business communication. Economics is a science that encompasses many areas, connected and not related to each other. For this reason, the difficulties of translating English terminology, corresponding to various economic spheres, are paid much attention to. Among the most common methods of translating economic terms from English into Russian, tracing, functional replacement and a combination of several methods of translation appeared to be dominant among the two-component and multicomponent terms, representing such spheres of economics as economics of enterprises, finance and banking, audit and accounting. The correlation links of the methods of term-formation and ways of translating English economic terms into Russian are outlined. However, it should be noted that this direction is only a small link in the chain of interactions representing economic life as a whole, which is constantly changing and improving. As a result the terminology inherent in such changes is changing, which, in turn, will lead to the emergence of new terms and new translation difficulties. The article gives some recommendations to teachers and translators on the problem discussed.

\section{References:}

1. Westworth G.F. Types of variants in terminological vocabulary. Problems of culture of the language of science and terminology. Vilnius, 1985. $265 \mathrm{p}$.

2. Бархударов Л.С. Язык и перевод. Москва : Международные отношения, 1975. 302

3. Виноградов В.С. Введение в переводоведение (общие и лексические вопросы). Москва : Изд.-во Института общего среднего образования РАО, 2001. $431 \mathrm{c}$.

4. Комиссаров В.Н. Современное переводоведение. 2-е изд., испр. Москва : Р. Валент, 2011. 408 с

5. Мисуно Е.А., Шаблыгина И.В. Перевод с английского языка: практикум : учеб. пособие. Минск : Аверсэв, 2009. 255 с.

6. Письменный перевод специальных текстов : учеб. пособие. / Е.А. Мисуно, И.В. Баценко, А.В. Вдовичев, С.А. Игнатова. Москва : ФЛИНТА : Наука, 2013. 256 с.

7. Пронина Р.Ф. Перевод английской научно-технической литературы. Москва : Высшая школа, 1996. 145 с.

8. Рецкер Я.И. Курс лекций по теории перевода. Москва, 2005. 141 с.

9. Розенталь Д.Э., Теленкова М.А. Словарь-справочник лингвистических терминов. Москва, 1998. 657 с.
10. Судовцев В.А. Научно-техническая информация и перевод: пособие по английскому языку : учеб. пособие. Москва : Высшая школа, 1989. $134 \mathrm{c}$.

11. Слепович В.С. Перевод (английский-русский) : учеб. пособие. Минск : ТетраСистемс, 2009. 336 с.

12. Жданова И.Ф. Новый англо-русский экономический словарь. 4-е изд. Москва : Русский язык - Медиа; Дрофа, 2008. 1025 с.

13. Пивовар А.Г. Большой финансово-экономический словарь / под ред. В.И. Осипова. Москва : Экзамен, 2000.

14. Dictionary of Economics / by J. Black. N.Y., Oxford University Press Inc., 2002.

Васильсва Т. Особливості перекладу англійських економічних термінів російською мовою

Анотація. У статті розглядається переклад економічних термінів, що користуються великим попитом через розвиток таких аспектів економічної діяльності, як банківська система, фінанси, аудит, облік, маркетинг, міжнародна торгівля. Метою перекладу економічних термінів $\epsilon$ передати найбільш правильний переклад 3 урахуванням відмінностей, що існують в економічних реаліях країн. У статті проаналізовано лексичні та граматичні ознаки та еквівалентність термінів. Підкреслюється, що через типологічні відмінності між російською та англійською мовами слід дотримуватися певних смислових відмінностей під час перекладу термінів. У статті розглянуто аналіз істотних характеристик, які визначають загальні та особливі поняття «термін», а також розкрито різні підходи вчених щодо методів перекладу термінів. У статті описано різні типи термінів із погляду морфології та відповідно до кількості їхніх складників і представлено аналіз найбільш поширених термінологічних моделей. Наведені в статті приклади доводять, що економічні терміни не можуть бути охарактеризовані як «лексичні одиниці», що непов'язані 3 контекстом. Наявність синонімічних зв'язків і неоднозначність підтверджують актуальність дослідження. У статті розглянуто вимоги до термінологічної лексики: точність, однозначність, стислість, послідовність, стилістична нейтральність, зв'язок із контекстом, відсутність синонімів та омонімів тощо. Оскільки в російській та англійській мовах багатокомпонентні терміни чисельно переважають над одноелементними, особлива увага приділяється різним методам перекладу багатокомпонентних термінів: калькуванню, використанню родового відмінка, функціональній заміні, стисненню, додаванню, модуляції, поєднанню декількох методів перекладу. Підкреслюється, що в процесі перекладу багатокомпонентних термінів необхідно провести семантико-синтаксичний аналіз, оскільки продуманий аналіз терміна є запорукою успішного перекладу.

Ключові слова: термін, економічний термін, метод перекладу, одноелементний термін, багатоелементний термін, термінологія, термінологічна модель. 